\title{
Violence and the Virtual: Right-wing, anti-asylum Facebook pages and the fomenting of political violence
}

Steffen Krüger (PhD), Dept. of Media and Communication, University of Oslo

\begin{abstract}
This article sheds light on the role of social media in the instigation of acts of physical violence. By combining content-analytical operations with the text-analytical method of scenic understanding, it identifies and interprets the major forms of interaction emerging from the interplay between page owners and users on German right-wing, antiasylum pages on Facebook. In this way, it brings to the fore these pages' interactional dynamic - a dynamic that, as I argue, prepares the ground for acts of physical violence (against foreigners, migrants, and asylum seekers). This ground is prepared through mainly two forms of interaction. Firstly, by gathering together dispersed news reports about crimes committed by foreigners and by condensing them into a provocative vision of reality, users are to be awakened to this reality ('How is it possible not to see what's going on?').

Secondly, by incessantly pointing to the intolerableness of this reality, the conclusion that users are to draw from their awakening is turned into a moral issue that goes to the core of their identities ('How is it possible to see what's going on and remain passive?'). In this way, a disposition is created that asks to be converted into a violent act.
\end{abstract}

\section{Introduction}

Numbers for the first half of 2016 presented by the German Ministry of the Interior show that politically motivated criminal acts against foreigners, refugees, and asylum seekers have more than doubled in comparison with 2015 (Spiegel Online 2016). Worryingly, this 
means the doubling of an already high number. Parallel to the increase of refugees and migrants coming to Germany in the second half of 2014 and throughout 2015 - with around 900,000 in 2015 (e.g. Welt 2016) - attacks either against refugees or their homes (or both) were already seven times higher in 2015 than 2014 (Reinfrank and Brausam 2016, p.235).

Coinciding with the drastically rising numbers of violent acts against foreigners, there has been a public debate in Germany on how much this violence is fomented on social media, and especially on Facebook pages operated by right-wing activists (Reinbold 2015; Bleich 2015). As far as this question of the specific role of online media is concerned, interpretations of the above numbers diverge. In the latest publication of the Leipziger Mitte ('Leipzig Centre') study on right-extremism in Germany, Reinfrank and Brausam (2016) claim that, for nearly every German city in which there have been violent attacks against foreigners or attacks against the places in which migrants and refugees are housed, there exists or existed a Facebook page dedicated to the abolition of such refugee homes (p.239), suggesting an intimate relation between symbolic interactions on social media and physical violent acts. The majority of the anti-asylum Facebook pages use the phrase Nein zum Heim ('No to the Home') a rhyming and catchy handle, followed by the name of their respective city, town, or region, for example 'Nein zum Heim in Oranienburg' and 'Nein zum Heim in Guben.' Coinciding with the increase of refugees arriving in Germany as well as the increase of violence against foreigners, a study conducted by the project No-Nazi.net, published in late October 2015, finds a parallel rise in Nein zum Heim Facebook pages from around 100 such pages in January 2015 to 225 in October (Netz-gegen-Nazis.de 2015). For mid-2016, Reinfrank and Brausam (2016, p.239) estimate over 300 such pages.

However, while the parallel developments in numbers strongly suggest an intimate relation between the emergence of the Nein zum Heim (i.e. anti-asylum) pages and the 
increase in violence against foreigners, other researchers are more cautious than Reinfrank and Brausam (2016) when interpreting the correlation. A comparison of the places in Germany for which there exist(ed) anti-asylum Facebook pages with the places in which refugee shelters and asylum seeker homes were attacked does not always point towards a direct causal link between activities on Facebook and 'violence in the streets' (Bleich 2015). As Johannes Baldauf, the head of No-Nazi.net, dryly stated in an interview: 'There were a lot of attacks in places for which there is not much happening in terms of "hate speech" on Facebook' (quoted in Bleich 2015). ${ }^{\text {ii }}$

Thus, as far as existing knowledge goes, the situation in Germany points to a rather ambiguous relationship between Facebook pages and right-extremist violence. At the national level, one can speak of a clear correlation between the increase in the numbers of refugees and migrants, violent acts against foreigners, and anti-migration activities on social media, especially on Facebook. Switching to a more fine-grained level of analysis, however, one can see that the correlations at the national level do not automatically result in direct cause-andeffect chains. Thus, while one can say with high probability that politically motivated physically violent acts are related to activities on Facebook, there is nothing in the various numbers at our disposal that would inform us about the quality and nature of this relation.

It is this quality of the relation between the Nein zum Heim Facebook pages and acts of physical violence against foreigners in Germany that is at the centre of this paper's interest. As a contribution to research into social media and violence (see, e.g., Patton et al. 2014), it inquires into the specific discursive and textual forms of symbolic interaction in which politically motivated violence against migrants and refugees is spoken about, suggested, and, as I will argue, fomented in the specific medial context of the Nein zum Heim anti-asylum Facebook pages. Thus, the question I am seeking to answer in this paper is: Do 
anti-asylum Facebook pages suggest and prepare the ground for acts of political violence and, if so, how?

Ultimately, what my study shows is that the analysed pages bring forth two interrelated forms of interaction (Lorenzer 1977) that are again intimately tied to the characteristics of digital, social media. The first form of interaction consists in accumulating news items on individual cases of criminal deeds committed by foreigners. These are condensed on the Nein zum Heim pages to a systematic and coherent picture of reality - a condensation that is made possible mainly through mechanisms characteristic of digital data - searchability, spreadability, and recontextualisability (boyd 2014, p.11). The second form of interaction consists in creating a disposition on the part of the mostly male page users (see footnote 9), not only to 'defend themselves' against foreigners, but also to defend against the threat of appearing emasculated and effeminate. This form of interaction, I argue, builds not only on a vagueness that is a key characteristic of populist communication (see Reinemann et al. 2017, p.16), but also on the very quality of virtuality (Shields 2003, 2006) of interactions online that continuously ask to become actualised. Put simply, I claim in this article that the Nein zum Heim Facebook pages indeed foment acts of politically motivated physical violence by (a) condensing individual news items into a dense and dark vision of an intolerable reality and (b) by turning the blemish of inaction in the face of this reality into a threat to the users' identity. Thus, there is a buildup towards violent acts, even if these acts cannot be deemed immediate results of the pages' communication and need not be found in direct relation to the pages and the places these pages refer to.

Before turning to my analysis, a few words on this study's bearings on ongoing concerns within media and communication studies. With my analysis being supported and informed by recent findings on right extremism and the status of democracy in Germany (Decker et al. 2016a), it is possible to address some of the questions that have been debated in 
media studies from a more concrete vantage point. Two of the issues to which my findings speak are the so-called reinforcement or 'echo chamber' effect of political communication online (Sunstein 2001, 2007) and the relation between media, its effects, and physical violence - a relation popularly captured in the question of whether use of (interaction with and/or consumption of) specific media (communication) lead(s) to violent behaviour on the part of the audience/users (for an overview, see Cantor 2003) - a reductionist and technodeterministic question closely tied to incidences of moral/media panic (Nicholas and O’Malley 2013).

In the following, then, I will first discuss recent sociological work upon which my analysis of the Nein zum Heim Facebook pages rests. Subsequently, I will present the major points of my analysis. I will close with theoretical observations as to the relation of social media and violence.

\section{Contextualising the relation between social media and violence}

The so-called Leipziger Mitte study has been conducted biannually since 2002, measuring the quality and virulence of antidemocratic, right-wing attitudes in Germany. A national survey based on Likert scale questionnaires and supplemented with in-depth, narrative interviews, the Leipziger Mitte study offers representative findings on right-extreme attitudes amongst the German population at-large (Decker et al. 2016a). ${ }^{\text {iii }}$ There is no particular focus on the role of media in this study, although some of the discussions refer to it (e.g. Reinfrank and Brausam 2016, see above).

Comparing results from 2016 with those from 2006, the latest findings are indeed worrying. As indicated by the increase in crimes against foreigners, Decker and his colleagues find clear signs that the antidemocratic, authoritarian, and right-wing milieus have become more extreme (Decker and Brähler 2016, p.16). In these circles, the political system 
has lost yet more trust, credibility, and legitimacy. While turning more radical, rightextremist groups in Germany now organise and experience themselves as political actors, with the right-wing party Alternative for Germany (AfD) managing to mobilise voters that before were bound to the mainstream Christian Democratic Union (CDU) and Social Democratic Party (SPD) (Decker and Brähler 2016, p.20). At the same time, in these rightextremist circles, violence as a means of contention is now more accepted than ever before. The group of right-extremists might not have increased in numbers, but its members now welcome the violent actions of others explicitly and are readier than ever before to use violence themselves (p.18).

On the other hand, Decker and his colleagues find that the number of people with democratic and/or conformist attitudes - that is, attitudes that support the status quo - has grown. Also, in the more conservative and conformist circles, which used to have a more ambivalent attitude to nondemocratic means of contention, violence is now strictly rejected as a way to reach goals, and the political system has gained significantly in legitimacy (Decker and Brähler 2016, p.18). In other words, throughout broad strata of German society, democratic attitudes have been strengthened. Thus, with the German mainstream more rooted in democratic ideals than ever before and an extremist margin that has never before been so loud, outspoken, self-confident, aggressive, and ready to use violence, the current situation in Germany has become decidedly polarised (Decker and Brähler 2016, p.19).

Returning to the question of the role of anti-asylum Facebook pages in relation to right-extremist violence against foreigners, the above results suggest the following: In view of the polarised relation between supporters of democratic ideals and extremists rejecting these ideals, it indeed seems highly probable that communication on online pages dedicated to the rejection and abolition of asylum seeker homes becomes homogenous and selfreinforcing, drawing mainly those that feel themselves in opposition to the German 
mainstream. Thus, in view of the radicalisation of extremists in Germany, their growing selfconfidence and, at the same time, alienation from the societal mainstream and its institutions, expecting a tendency towards 'online homophily,' that is, the 'tendency of similar individuals to form ties with each other' (Colleoni et al. 2014, p.318), and the echo chamber-like reinforcement of prior political views on the anti-asylum Facebook pages seems to be very plausible. Indeed, as my analysis shows, this is clearly the case on the Nein zum Heim pages. ${ }^{\text {iv }}$

Generally speaking, in light of a political situation in which right-extremists are developing their political self-identity in an agonistic and radical opposition to the political mainstream, it becomes possible to see how online discussions are increasingly being conducted amongst the likeminded only, and how extremist views become reinforced in 'chambers' that carry sound on the inside, but are nearly isolated to the outside. Facebook's newsfeed algorithm, which determines which followers are being served posts by whom (Hamilton et al. 2014) amplifies this effect (Pariser 2011).

Against the above, it also becomes perceivable how online symbolic interactions amongst extremists will foment political violence against others and in the face of a majority that appears to firmly side with the status quo. Even though much of the rhetoric on the antiasylum pages is about 'awakening' a slumbering majority, ${ }^{\mathrm{v}}$ the worse extremists perceive their chances of successfully reaching out to this majority with arguments, the less interested they will be in using symbolic means of persuasion outside their core group. Therefore, whereas psychoanalytically informed theories of subjectivity do not allow for the conception of a direct link between speech acts and acts of physical violence, ${ }^{\mathrm{vi}}$ the sociocultural setting within which the anti-asylum pages operate suggests an intimate relation between the two nevertheless. Against the polarised situation between democratic and antidemocratic milieus, a significant part of the communication amongst right-extremists online orbits around the 
uselessness, meaninglessness, and futileness of communication. It is in this atmosphere that the idea of violence emerges as a logical response.

\section{The Nein zum Heim pages - existing research}

Since the Nein zum Heim pages are a relatively recent online phenomenon, with most of them not going back further than 2014, not much analytical work has been done on them specifically. ${ }^{\text {vii }}$ The Amadeu-Antonio Foundation (2016), a right-extremism monitoring group, published a 20-page booklet titled Agitation Against Refugees in Social Media (2016) that takes up the Nein zum Heim pages. Another brief analysis is offered in a journalistic article by Martin Giesler (2016). Both contributions offer brief content analyses of the pages. The booklet by the Amadeu-Antonio Foundation (2016) gives an overview of typical rhetorical means of agitation against refugees and foreigners online, such as sweeping generalisations, scapegoating, and the construction of an opposition between 'them' and 'us.' Giesler (2016) in turn divides the pages' posts into five main categories: xenophobic agitation, intended fearmongering, cheap populism, call to (participate in) demonstrations, and right-wing 'jokes.' While both contributions offer important tools for detecting right-wing agitation online in general, the value of their analyses becomes somewhat limited in that they do not aim at an understanding of how the individual modes of communication combine to give shape to a specific vision of reality and, with it, a disposition to act.

\section{Selection of material}

With the aim of this study being to first identify the most pertinent forms of interaction on the Nein zum Heim anti-asylum pages, so as to then submit these to in-depth, qualitative analysis, the empirical base for this study consists of an exemplary choice of Nein zum Heim pages, but one closely representative of all existing pages: 
- 'Nein zum Heim in Guben.' As the biggest of the anti-asylum Facebook pages in existence, with more than 10,000 'likes'viii (in comparison to just about 18,000 inhabitants of Guben [Giesler 2016]), it is the clearest example of how these pages can reach people far beyond their local point of reference.

- 'Nein zum Heim in Schwarzwald-Baar-Heuberg.' While numbers as high as several thousand 'likes' are only achieved by pages located in former East Germany (with Guben being one of them), the Schwarzwald-Baar-Heuberg page is one of the biggest pages for West Germany, with 1,900 'likes.' As with the Guben page, it refers to a rural, non-urban area.

- 'Nein zum Heim in Köpenick.' With 6,400 'likes,' the Köpenick page is one of the most 'liked' pages with an urban, East German reference point. (Köpenick is part of Berlin.)

- 'Nein zum Heim in Oranienburg' refers to a place geographically close to Köpenick. With 3,300 'likes,' the page is still one of the most successful. I have included it in the analysis to be able to check for similarities and differences between two pages in close geographical proximity. (This aspect will not become relevant for the present paper.)

- 'Nein zum Heim in Freiburg' and 'Nein zum Heim in Trier.' These pages have comparatively small followings. With 550 'likes' for Freiburg and 650 'likes' for Trier, they are typical for pages referring to more urban areas in West Germany.

My analysis is based on the main posts on the listed pages published over the first nine months of 2016 (from 1 January 2016 to 22 September 2016, or 266 days), including the user comments in response to these posts. Regarding the number of main posts, the Schwarzwald- 
Baar-Heuberg page has had the highest output with 561 published posts. This is followed by Guben with 527 posts. Köpenick published 330 posts within the same time span. Its neighbouring district, Oranienburg, with nearly 180 posts, makes it to little more than half that. Freiburg published a mere 30 posts within the time span, a scarcity that puts a question mark above the functionality of the page. The Trier page only started in August 2016; within a month, from 22 August until 22 September, its administrators posted 31 times. The total number of posts selected for analysis is thus 1,659 posts.

The above numbers translate into the following frequencies: On average, the Schwarzwald-Baar-Heuberg page posted a little more than twice per day (2.1 posts/day); Guben posted content to its page very nearly twice a day (1.98 posts/day); Köpenick more than once a day (1.24 posts/day), Trier once a day, Oranienburg a little more than once every other day (0.66 posts/day) and Freiburg not even once a week, only every ninth day $(0.11$ posts/day). What can be deduced from these numbers is the intention of most pages to have a frequent, regular output of posts and to become a steady part of their users' everyday lives.

In terms of user interaction, however, the numbers are modest. Even the Guben page, as the most 'liked,' does not often manage to generate triple-digit numbers of 'likes' or 'shares' on its posts. On average it receives between 60 and 70 'likes,' between 50 and 60 'shares' and between 5 and 15 comments, with numbers diverging vastly however. ${ }^{\text {ix }}$ For the smaller pages, the 'interaction stats' were respectively lower, with the West German pages at the bottom end. The Schwarzwald-Baar-Heuberg page, for example, receives very little in return for all its activity. With more than two posts per day, there are hardly any 'like' numbers that are over 10 and barely any 'shares' and comments.

Overall, comparing the Nein zum Heim Facebook pages with those of a similar political orientation, such as 'Identitäre Bewegung - Deutschland' ('Identitarian Movement') or 'Wir für Deutschland' ('We for Germany'), which are designed to operate at the national level and 
which have follower numbers of more than 40,000, the Nein zum Heim pages' follower counts appear insignificant. However, in view of the high numbers of existing Nein zum Heim pages - with the latest estimate being over 300 (Reinfrank and Brausam 2016, p.239) and in view of their local reference point, their grassroots activist, plebiscitary intent, and their populist appeal to the 'people,' the anti-asylum pages are relevant in that they convey a more straightforward appeal to action. Indeed, as can be gathered from the relatively low numbers of 'likes,' 'shares' and comments and as could be expected in view of the findings of the Leipziger Mitte study (Decker and Brähler 2016), in most cases, the interaction on the pages is that of a small community consisting of the page owners and a relatively small number of active, faithful followers, most of whom are male, ${ }^{\mathrm{x}}$ who interact with one another with little interference from outside. However, as also suggested above, it is in such closely knit and closed-off communities that the anti-asylum pages unfold their appeal - an appeal, which, as I will show, paradoxically is caught in a repetitive loop of the message that the time for talking is over.

\section{Identifying and interpreting typical forms of interaction - methodological reflections}

My analysis is based on a mix of content and text analysis, backed up by simple corpus-analytical operations. Initially, an analysis of the content of the posts on the selected Nein zum Heim pages during the analysed time span served to work out the central forms of interaction that dominate and determine the pages' character. Consecutively, I used 'scenic understanding,' a hermeneutic method of analysing texts and other cultural artefacts (e.g. Lorenzer, 1970, 1986) to analyse the forms of interaction worked out in the content analysis. Scenic understanding is geared to detect inherent conflicts and contradictions in a given material. Like discourse analysis (e.g. Potter and Wetherell 1987), scenic understanding focuses on paradoxical formulations and inconsistencies in texts, such as gaps and broken off 
sentences, striking words and terms, repetitions, missing conclusions, and so forth. It understands such events quite literally to be 'making a scene' that involves not only a text's dramatis personae, but also its audience (i.e. readers/users), which a given scene pulls towards itself. Consequently, scenic understanding interprets texts and cultural materials for their socialising effects on their audiences. It is this interest in how content, form, and effect go together which makes the method an interesting fit for the analysis of right-extremist online pages and their social impact. To support the findings of the scenic analysis, I used observations gained from simple corpus-analytical operations (i.e. word lists; see, e.g., McEnery et al. 2006 and footnotes 10, 11, and 14).

\section{Analysis - Forms of interaction on the Nein zum Heim pages}

The content analysis of the selected Nein zum Heim pages resulted in no more than three core forms of interaction central to all analysed pages. At a basic, formal level, these can be described as (a) the re-posting and sharing of news items and press reports found on other internet sites, which serves a journalistic, reporting function; (b) the posting and sharing of opinion pieces in the form of filmed speeches or monologues, or written epigrams and aphorisms, often in a layout consisting of fat print combined with eye-catching images, which serve the function of a political comment; and (c) spreading information regarding demonstrations - either calls for upcoming demonstrations or documentation of past ones which is to have an activating function. In terms of quantity, while the reporting function, that is, the re-posting of news items from other sources, is clearly the main activity of all pages, with over 50 percent of all posts serving this function, the number of opinion pieces ranges from 15 to over 30 percent. While calls for and reports on demonstrations are also standard on all pages, they occur significantly less frequently than the other two, with around 10 to 20 percent of all posts belonging to this genre. 
As indicated by the relative frequency of the three forms of interaction on the pages, it is mainly the first two - the sharing of news items and posting of opinion pieces - that are relevant to the kind of disposition created by the pages. Indeed, the following analysis points to the third form of interaction - the calls for demonstractions - as being a screen behind which the build up of violent acts can be made to hide.

\section{Form of Interaction I: Condensing the dispersed into the characteristic}

Invariably, the kinds of news items that become re-posted and shared on all antiasylum Facebook pages are those in which foreigners, migrants, and/or asylum seekers are reported to have committed criminal acts and/or pose a threat to ethnic Germans and social order. Thus, the function at the core of all Nein zum Heim pages is to accumulate and gather together the reports of asylum seekers 'flooding' Germany, of regions and cities becoming overwhelmed by the burden of the incoming 'masses,' of cases of sexual assault and/or rape committed by foreigners against ethnic German women, of robberies, knife attacks, and mass brawls in asylum seeker homes, of fights between asylum seekers and ethnic Germans, of indecent behaviour in public pools and on public transportation, of asylum seekers tricking and exploiting the German welfare system, of displays of insolence or ingratitude towards the German 'hosts,' of the helpers' naivety, and, not least, of the ignorant, arrogant, and incompetent government that tolerates the above.

Strikingly, the more successful anti-asylum pages all have developed a trademark gesture with which they routinely introduce these news items of criminal foreigners to their followers. The Köpenick page, for example, introduces many of the news items with a dry and seemingly detached phrase Zur Info, which is colloquial for FYI (for your information). ${ }^{\mathrm{xi}}$ With repetition, this emphasis on the neutral, informational character of the interaction brings 
to the fore an emotional attitude that appears to have spent itself. It performs the quasicatatonic emptiness of affect characteristic of those that have turned numb through a process of traumatisation over time. 'It is just too shocking to be real, but real nevertheless,' the gesture seems to say. The Oranienburg page, in turn, prefaces several of the shared news reports with 'welcome': 'Welcome to Oranienburg,' 'Welcome to Germany,' 'Welcome to the loony bin.' The 'ship of fools' motif that thus comes to the fore underlines the apparently incredulous attitude of the page owners to the reality behind the news they spread.

The most provocative and informative of these gestures, however, can be found on the Guben page. It is a gesture, I argue, that unlocks the meaning of the entire act of sharing news items on the Nein zum Heim pages. On the Guben page, the news items of criminal misdemeanours by foreigners are introduced with variations of the word Einzelfall, meaning an 'individual' or 'unconnected case' or 'incident,' for example 'another unconnected incident,' 'all unconnected cases,' and 'just an individual case. ${ }^{\text {xii }}$ This repetitive reference to the news reports as Einzelfälle builds up a laconic, cynical attitude. It is to make clear that these reported incidences are the exact opposite of individual, unconnected cases. To the contrary, what is implied - or better: what is achieved - by the continuous, unending stream of case after case of crimes by foreigners on the pages is a vision of reality in which these crimes take on a systematic, unstoppable, and all-consuming character that threatens to subvert the German people and in which foreigners are attributed a natural proclivity to crime and an unfixable lack of adaptability to the host culture.

Furthermore, while existing studies have claimed that the news reports shared on the anti-asylum pages are frequently fakes (Giesler 2016; Bleich 2015), my reading cannot verify this. To be sure, not all reports posted on the pages are credible. The site Hoaxmap offers a non-exhaustive overview of the known cases of fake reports (see also my analysis of the fakes collected there: Krüger 2017). Moreover, not all news sources used on the pages can be 
deemed trustworthy, with many of them following a clear political agenda, as for example Compact-Online.de, RT-Deutsch, Kein-Freiwild.info, and AnonymousNews.ru. That there is indeed a wish on the part of the makers of many of the anti-asylum pages to actively and intentionally fabricate a picture of reality can be gathered from the incidences in which older news items, which had already been posted once, are recycled and posted once again as current events. However, these instances seem to be neither particularly effective nor at all welcomed by the Nein zum Heim users, who often comment negatively on this practice. For example, when on 2 August 2016 the Schwarzwald-Baar-Heuberg page reused an article from the newspaper Bild headlined 'Too many refugees - the city of Munich calls out a case of disaster' (Riechers 2015), originally published in the summer of 2015, a user complains 'What's that shit??? From 2015[.] Are you feeling quite alright?'

All in all, the number of cases of straightforward fakes is relatively low and should not be taken as the pages' core activity. Rather, while there clearly is the wish to construct a reality that is biased towards a certain point of view, this is not done with fake news but rather by accumulating authentic reports on individual cases of criminal acts committed by foreigners from credible sources. Thus, in most cases, reports are verified and taken from established news sources. ${ }^{\text {xii }}$ Clearly, (moderately) right-conservative news sources, such as Focus, are preferred, and left-liberal sources such as Spiegel or Die Zeit are linked to only with dismaying remarks, so as to retain ideological distance to them. Another source that is relatively often used by the Nein zum Heim pages are police report portals - a practice that goes well together with the findings of the Leipziger Mitte study that the police enjoy the highest degree of trust amongst the German population (Decker et al. 2016b, p. 59).

Yet, the sources whose use is most telling in view of the strategy pursued by the antiasylum pages are local and/or regional news sources that, astonishingly, are often located outside the region to which the respective Nein zum Heim page refers. For example, reports 
from Munich, Bonn, or the Ruhr area can be found on the Guben page, which is far away from these places, and news from Niederlausitz is posted on the Schwarzwald-Beer-Heuberg page. ${ }^{\text {xiv }}$ What shows in this utilisation of dispersed news items from all over Germany, as well as Austria and German-speaking Switzerland, is a possibility facilitated by and characteristic of digital, social media. The potential loss of context of information online and the effortless de- and re-contextualisation of information so often debated in relation to the digital (e.g. boyd 2014, p. 8ff.), unfolds here in the form of an ongoing act of condensation that merges together the dispersed and unconnected and assembles it into an overdetermined picture of a reality in which these cases appear as exactly not dispersed and individual, but as an ongoing process resulting in a highly meaningful picture of reality. ${ }^{\mathrm{xv}}$

\section{Form of Interaction II: Enduring unendurable injustice}

The opinion pieces - that is, the posts of statements and aphorisms, editorial comments, and videos of speeches and monologues - as the other main element of the antiasylum pages go hand in hand with the sharing of news items and the construction of reality as the result of their condensation. While already the news items and the gestures accompanying them, such as 'Welcome to the loony bin' (see above), set a distinctly agonistic mood, the opinion pieces unpack this mood further by tirelessly emphasising the ongoing, incessant abuse and exploitation of ethnic Germans reported in the news items. Consequently, the atmosphere created by them is tragic, brooding, Cassandra-like, and apocalyptic, foreseeing the end of the German people and their replacement by foreigners.

Having specialised in memes with political statements, the Guben page is most illustrative of the disposition that is to be created amongst the core users. For example, one 
such meme from 21 June 2016 uses a motive from the movie $V$ for Vendetta - a shadowy outline of a male figure in a dark robe, with a Zorro-like hat, long hair, and a Guy Fawkes mask (made prominent by the film and then elevated to notoriety by the 4-chan-born Anonymous movement). The statement written in white upon the backdrop created by the black robe reads: 'What right does our political elite have to claim almost 50\% of our work, but refuse to secure the country's borders and property and to protect the population?' In this particular case, it seems somewhat unclear whether it is the political elite that is to be identified with the shadowy figure, or whether it is the page owners and users, who in continuing the tradition of Anonymous, are to avenge the 'common people' for the deeds done against them by their government and those against which the government fails to protect them. The distribution of sentiments, however, is clearly in line with what Aalberg and de Vreese (2017, p.10) call 'complete populism,' which, as they state 'includes reference and appeals to the people, as well as anti-elitism and exclusion of out-groups.' As Reinemann et al. state, this 'complete populism' is characteristic mainly of right-wing populism (2017, p.15).

The distribution of loyalties, affiliations, and hostilities along the lines of complete, right-wing populism can be witnessed in a significant number of posts. To offer another example from ‘Nein zum Heim in Guben' from 15 January 2016: 'Only idiots allow that, due to open borders, they become the minority in their own country!!!' Since it was the Merkelled, CDU government that had opened the borders to asylum seekers in the summer of 2015 (e.g. Zeit Online 2016) and since it is asylum seekers and migrants who, in the imagination of the authors of this post, will be the root cause for Germans becoming the minority in their own country, the double opposition of right-wing populism towards the political elite and an outgroup is actualised in this post. 
On average, the Guben page publishes such posts, frequently with a tombstone-esque design, every second to third day (over 30 percent of all posts), creating an overall pathos of injustice and suffering - a suffering that must appear endless, since the stream of migrants coming to the country as well as the stream of news items found on the internet about criminal foreigners does not end either. Through tireless variations and repetitions of the same plaint over time, what is produced is an impression of utter victimhood and stagnation. Despite all the information, all the warnings and complaints, the humiliation and violation of the German people goes on regardless, is the conclusion that the opinion pieces amount to. However, while these pieces claim to merely point to the injustice done, they actively produce the feeling of ongoing injustice and the vision of reality to go with it. In this way, the form of interaction that emerges from the opinion pieces is the suffering of an injustice that should be endured no more.

\section{The pleasure of endurance and its backlash}

In the above form of interaction, however, resides the central conflict that the Nein zum Heim pages produce. Whereas, time and again, the injustice suffered at the hand of foreigners and the government is shown as unbearable, the unending stream of news of this injustice makes clear that, paradoxically, it is born and endured and must therefore be somehow bearable nevertheless. This is not unproblematic, since this contradiction holds an incriminating potential. If that which should not - must not - be endured is endured nevertheless, the suffering resulting from it is under suspicion of containing a degree of pleasure, or even neediness.

Sara Ahmed (2014, p.51) writes that the emotion of hate not only seeks to destroy the object that it constructs as other, but that it also forms a mode of attachment that must 
conserve the hated object because it needs it for its own identity formation. This seems to be realised on the anti-asylum Facebook pages in the form of the unending stream of plaints. In these plaints, fantasies of an aggressive pleasure to hurt are located in the out-group of foreigners and a pleasure to watch others suffer are placed within the government and the political elites. This distribution of pleasures, however, tacitly suggests a third such pleasure, namely, that of passively suffering, of receiving pain, on the part of the ethnic Germans.

Now, it is not hard to see why this suggestion of a pleasurable suffering must appear completely inacceptable to the page users and as a threat to their identities. Interestingly, however, I want to argue that this is exactly what the Nein zum Heim pages provoke by repeating their plaints over and again. This is reality! and This is how we suffer! are the two provocations emanating from the pages. Ultimately, then, the turn to violent acts against foreigners and/or politicians emerge as a viable mode to defend oneself, not only against these others, but first and foremost against the threat of being seen as impassive, emasculated, or straightforwardly perverse which is implied in the possibility of enjoying one's own suffering. It is the response to this threat - that If I remain passive, this means that I tacitly give my consent, or worse, secretly enjoy my suffering - which is at the heart of the affective disposition that the Nein zum Heim pages create.

\section{'Our women and children' - gender dynamics}

Clearly, this disposition is built on a gendered dynamic, with a major threat being that the majority male page users might be seen, or see themselves, as effeminate. Nancy Chodorow, in her article 'Hate, Humiliation and Masculinity' (2012), works out two major 'fault lines of masculinity and male selfhood' that account for a specific proneness to violence in men (p.134). First, 'masculinity as not-female, and the male self as defensively 
separate from and warding off the female other, and second, maleness as adult man rather than boy-child, not humiliated, shamed, or defeated by another man' (p.134). These fault lines clearly play a role in the dynamics unfolding on the anti-asylum pages, where, in the shared news items, it is almost invariably women who become attacked, assaulted, groped, or approached in an indecent manner (with the events on New Year's Eve in Cologne and other cities in Germany [see Amjahid et al. 2016], where women were assaulted by large groups of mostly North African men, being at the core of this narrative). In the shared opinion pieces, in turn, it is 'our women and children' who need to be protected from the 'barbarous hordes.' However, while this concern about women and children firmly positions those who are concerned as male, the continuing stream of news reports of such assaults implies that this maleness is not intact. After all, the reports are proof that page owners and users have not managed to protect their women and children - yet.

\section{The threat of the feminine in populism}

Interestingly, this problematic notion of maleness and masculinity can also be encountered in the dynamics of populism. As Reinemann et al. (2017, p.16) observe, there is a vagueness in populist communication that can be seen as 'one of the key characteristics' and an 'important reason for the success of populist messages.' On the Nein zum Heim pages, this vagueness is most salient as regards the question of what action should be taken in response to the threat that foreigners pose. In other words, it is in the provocatively 'real not real' quality (Yates 2015, p.22) with which acts of violence are alluded to that a populist vagueness is performed on the pages.

One can say the page owners are flirting with violence in their posts, and, indeed, for the case of the Nein zum Heim pages, the vagueness found in populism seems to be best 
captured in the concept of flirtation (Yates 2015, p. 22ff.). Being associated with coquetry, dalliance and play and connoting a lack of seriousness, Candida Yates notes in her assessment of flirtation that

the cultural distrust of flirtation as a mode of relating is reflected in psychoanalytic discourse where flirtation becomes a signifier of lightweight, superficial human relations and aligned with the image of the coquette as the seductive, if shallow, feminine other. (Yates 2015, p.33)

In order to avoid this identification with the female other, with dallying, not being serious, and being effeminate, what the Nein zum Heim pages build up over time is the belief that an act is needed that will stabilise the users' identity as male. And with maleness being intimately tied to ideas of power and domination (Chodorow 2012, p.126), this act must be a violent one, since nowhere is domination more radically asserted than in violence.

Form of Interaction III -

\section{Calls for demonstrations as a screen}

It is in view of the above disposition, built up on the Nein zum Heim pages, that the third form of interaction, that is, the calls for and reports on demonstrations, cannot be seen as adequate outlets for this disposition. The term 'evening walk, for example, which is regularly used on the Oranienburg page to emphasise the peacefulness of the demonstrations, again threatens to unfold effeminate connotations, evoking the figure of the flaneur, "whose voyeuristic gaze allows him to live his life one step removed from the stresses of emotional engagement in a transitory context' (Yates 2015, p.25). In this view, the calls for 
demonstrations must be seen as a screen in the psychoanalytic sense of repressed elements and a defence against them (see 'screen memory' in Laplanche and Pontalis 1973).

A Text reading itself - the relation between posts and user comments

That acts of violence are indeed what are tacitly suggested by the pages becomes perceivable from the ways in which users complement and, indeed, complete the main posts. What one thus finds on all analysed pages is a substantial number of comments that suggest an openly violent attitude as a direct continuation of the main posts. To list only a few examples:

- In response to the sexual assaults in Cologne on New Year's Eve, 2015/16: 'If the judiciary does not speak a couple of sensible verdicts soon, the people will soon take the sentencing of perpetrators into their own hands.' And another: 'In situations of self-defence one can/is allowed to use anti-animal spray. This situation would be fully justified.' And yet another: 'Unfortunately we are not allowed to defend ourselves because in this country vigilante justice is forbidden. rather we have to put up with everything from this fucking pack........ but beware one carries an alarm gun, a baton or pepper spray one gets punished and reported to the police as a racist and nazi.......but those fucking asys [asylum seekers] can do everything, they also get everything........ thank you you depraved sh [sic]' ('Nein zum Heim in Guben,' 2 August 2016).

- In response to a post advertising 'Five legal and highly effective weapons for the defence of one's own life': 'All that's fun is forbidden! ! But seriously, who doesn't give a shit with what he defends himself, whether it pleases the ladies and gentlemen 
that got us into that [mess] or not., the main thing is that one can defend oneself when it is necessary.' ('Nein zum Heim in Schwarzwald-Beer-Heuberg,' 22 August 2016)

- And in response to the news in Hamburger Morgenpost of a foreigner being beaten unconscious by four men after having tried to grope a woman: ‘ही $\square$ (ृ.

The dynamic which I take these examples to highlight should by no means be regarded as one that comes with a degree of freedom or looseness, that is one that might or might not result in the dangerous play with and suggestions of violence shown above. To the contrary, it is my point here that the quoted comments are the psycho-logical conclusion to the disposition created by the main posts of the Nein zum Heim pages. They are the consequence of the forms of interaction initiated there. Together, main posts and user comments constitute what Bown and Bristow (2013) call a text that reads itself, meaning a text that 'no longer simply imposes its shock effect on us when reading it' but that, by virtue of the online comments it sows and harvests, 'shocks itself into betraying its true content' (p.62).

\section{Conclusion}

This study does not claim any direct relation between symbolic interaction and physical acts of violence. Rather, one could say that physical violence always marks the breakdown and collapse of the symbolic realm. Yet, what I hope my analysis of German antiasylum Facebook pages has brought to the fore is that it is exactly such a breakdown of communication and symbolic interaction that the Nein zum Heim pages work towards. By gathering news items of criminal deeds committed by foreigners and by condensing these into an agonistic reality in which sexual assault, rape, brutality, and disrespect are the order 
of the day and by depicting this reality as the cause for the ethnic Germans' suffering, the conclusion which emerges from these provocations can only be to 'fight back.'

This psycho-logic is further exacerbated by the deadlock quality of the reality performed by the anti-asylum pages. Even though reality is unbearable, the posts on the pages show that it persists. And even though the resulting suffering is shown to be intolerable, the continuous stream of posts implies that it is in fact tolerated. Thus, through this notion of being stuck, powerless, and impotent, which arises over time, acting up becomes an identity issue. After all, one's self-image as proper, decent, and 'for real' comes to depend upon taking action. Furthermore, since this identity is defined as male and depends on traditional notions of masculinity, the call for demonstrations and invitations to so-called 'evening walks' xvi cannot be seen as a viable way to vent the emotional disposition built up on the pages. Rather, the threat of humiliation can only be stamped out by an act that eradicates all possible association with passivity, immaturity, and femininity.

Also in this respect, online, digital media in general and Facebook in particular play a major role, but not in the way frequently articulated in mainstream news, where Facebook has been accused of applying an excessively liberal understanding of free speech to incidences of hate speech on its platform. While this might well be so, the present analysis shows that it is more general qualities of the digital that play into the build-up of the affective disposition fostered on the Nein zum Heim pages. It is the characteristic qualities of digital data in online networks - persistence, visibility, spreadability, and searchability (boyd 2014, p.11), as well as impartiality (in terms of context and meaning) and manipulability (Miller 2011, p. 75) - that facilitate the condensation of the dispersed that is at the heart of the vision of reality constructed by the Nein zum Heim pages.

But that is not all. Rather, also the threat of the feminine - of becoming incriminated by one's own impassivity on part of the male users - seems to be something that is partly 
derived from a dynamic inherent to online interactions at large. More precisely, it seems that the virtual itself - that is, the very mode of reality shared by all online encounters - plays a role in fomenting the kind of violence that the pages suggest. Poignantly, this is captured in the appeal of one of the commentators to the pages who, in response to a terror warning, writes: 'People, please wake up already...open your eyes and finally use them to see, instead of hunting pokemons' ('Nein zum Heim Oranienburg,' 22 July 2016). The reference to the popular augmented reality game Pokémon Go is key here. In the game, people use their smartphones to roam the physical world in order to catch virtual cartoon monsters that the game app superimposes onto the physical environment shown on the phone's screen. While moving in the 'real,' physical world, players do not purposefully engage with it. What the comment thus points to is a playful lightness and lack of consequence inherent in virtual (digital) communication that seems to haunt the participants on the Nein zum Heim pages.

Drawing on Marcel Proust, Rob Shields (2006, p.284) defines the virtual as 'real without being actual, ideal without being abstract.' This means that, in order to be turned into actual reality, the virtual needs to be actualised. Arguably, this is exactly what the Nein zum Heim pages tacitly require of their users. Just as in Shields' example of the child claiming 'to have "virtually completed" their homework' (2006, p.284), virtuality and virtue go together also on the anti-asylum pages, where the ideal reality refers just as much to the user's selfidentity - to the user's ego-ideal. And while the pages indeed suggest that the act which actualises the ideal reality of the virtual is 'virtually completed,' the user still needs to fulfill this promise. This promise, however - the act - can never be the direct concretisation of the virtual of the Nein zum Heim pages, but always retains its distance and mediatedness. 'Actualization is performative,' writes Shields (2006, p.285), 'the Virtual itself is a multiplicity which can be actualized in different ways. If it is known by its effects, then it is known through a specific instantiation, not as a whole.' 


\section{References}

Aalberg, T., \& de Vreese, C. H. (2017). Comprehending populist political communication. In

T. Aalberg, F. Esser, C. Reinemann, J. Stromback, \& C. H. de Vreese

(Eds.), Populist political communication in Europe (pp. 3-11) London and New York:

Routledge.

Ahmed, S. (2014). The cultural politics of emotion (2 $2^{\text {nd }}$ ed.). Edinburgh: Edinburgh

University Press.

Amadeu-Antonio Foundation. (2016). Hetze gegen Flüchtlinge in Sozialen MedienHandlungsempfehlungen. Berlin: Amadeu-Antonio Stiftung.

Amjahid, M., Fuchs, C., Guinan-Bank, V., Kunze, A., Lebert, S., Mondial, S., ... Rieth, S.

(2016, June 28). Was geschah wirklich? Die Silvesternacht von Köln. Zeitmagazin. Retrieved

October 31, 2016 from http://www.zeit.de/zeit-magazin/2016/27/silvesternacht-koeln-

fluechtlingsdebatte-aufklaerung.

Berntzen, L. E., \& Weisskircher, M. (2016). Anti-Islamic PEGIDA beyond Germany:

Explaining differences in mobilisation. Journal of Intercultural Studies, 37(6), 556-573.

Bleich, H. (2015, December 11). Rassisten in der Filterblase - 'Hate Speech' auf sozialen

Plattformen und was dagegen hilft. c't-Magazin für Computer und Technik. Retrieved 
October 30, 2016 from http://www.heise.de/ct/ausgabe/2015-27-Hate-Speech-auf-sozialenPlattformen-und-was-dagegen-hilft-3032127.html.

Bown, A., \& Bristow, D. (2013). Why are animals funny? Everyday analysis from the EDA collective. Winchester, UK and Washington, DC.: zero books.

boyd, d. (2014). It's complicated: The social lives of networked teens. New Haven and London: Yale University Press.

Cantor, J. (2003). Media violence and its effect on aggression: Assessing the scientific evidence. Journalism \& Mass Communication Quarterly, 80(2), 468-470.

Chodorow, N. (2012). Individualising gender and sexuality: Theory and practice. London and New York: Routledge.

Colleoni, E., Rozza, A., \& Arvidsson, A. (2014). Echo chamber or public sphere? Predicting political orientation and measuring political homophily in Twitter using big data. Journal of Communication, 64(2), 317-332.

Decker, O., \& Brähler, E. (2016). Autoritäre Dynamiken: Ergebnisse der bisherigen 'Mitte'Studien und Fragestellung. In O. Decker, J. Kiess, \& E. Brähler (Eds.), Die enthemmte Mitte. Autoritäre und rechtsextreme Einstellung in Deutschland (pp. 11-22). Giessen: Psychosozial.

Decker, O., Kiess, J., \& Brähler, E. (Eds.). (2016a). Die enthemmte Mitte. Autoritäre und rechtsextreme Einstellung in Deutschland. Giessen: Psychosozial. 
Decker, O., Kiess, J., Eggers, E., \& Brähler, E. (2016b). Die 'Mitte'-Studie 2016: Methode, Ergebnisse und Langzeitverlauf. In O. Decker, J. Kiess, \& Brähler, E. (Eds.), Die enthemmte Mitte. Autoritäre und rechtsextreme Einstellung in Deutschland (pp. 23-66) Giessen: Psychosozial.

Giesler, M. (2016, April 12). Wie die Rechten ungestört auf Facebook wüten. bento. Retrieved October 30, 2016, from http://www.bento.de/politik/nein-zum-heim-wie-dierechten-auf-facebook-agieren-105078/.

Hamilton, K., Karahalios, K., Eslami, M., \& Sandvig, C. (2014, April). A path to understanding the effects of algorithm awareness. Conference on Human Factors in Computing Systems - Proceedings (pp. 631-640). ACM.

Krüger, S. (2017). Barbarous hordes, brutal elites: The traumatic structure of right-wing populism. e-flux Journal, 83. Retrieved April 3, 2018, from http://www.eflux.com/journal/83/142185/barbarous-hordes-brutal-elites-the-traumatic-structure-of-rightwing-populism/.

Laplanche, J., \& Pontalis, J.-B. (1973). The language of psychoanalysis. London: Hogarth Press and the Institute of Psycho-Analysis.

Lorenzer, A. (1970). Sprachzerstörung und Rekonstruktion. Vorarbeiten zu einer Metatheorie der Psychoanalyse. Frankfurt/M: Suhrkamp. 
Lorenzer, A. (1977). Sprachspiel und Interaktionsformen. Vorträge und Aufsätze zu Psychoanalyse, Sprache und Praxis. Frankfurt/M.: Suhrkamp.

Lorenzer, A. (1986). Tiefenhermeneutische Kulturanalyse. In A. Lorenzer (Ed.), KulturAnalysen: Psychoanalytische Studien zur Kultur (pp. 11-98) Frankfurt/M.: Fischer.

McEnery, T., Xiao, R., \& Tono, Y. (2006). Corpus-based language studies: An advanced research book. New York and London: Routledge.

Miller, V. (2011). Understanding digital culture. London: Sage.

Netz-gegen-Nazis.de. (2015, October 22). Monitoring: 225 mal 'Nein zum Heim' auf Facebook. Retrieved October 30, 2016, from http://www.netz-gegennazis.de/artikel/monitoring-225-mal-nein-zum-heim-auf-facebook-10642.

Neumayer, C. (2016). Nationalist and anti-fascist movements in social media. In A. Bruns, G. Enli, E. Skogerbø, A. O. Larsson, \& C. Christensen (Eds.), The Routledge companion to social media and politics (pp. 296-308) .New York and London: Routledge.

Nicholas, S., \& O’Malley, T. (2013). Moral panics, social fears and the media: Historical perspectives. London and New York: Routledge.

Pariser, E. (2011). The filter bubble: What the internet is hiding from you. London: Penguin. 
Plessner, H. (1982). Mit anderen Augen. Aspekte einer philosophischen Anthropologie. Stuttgart: Reklam.

Potter, J., \& Wetherell, M. (1987). Discourse and social psychology: Beyond attitudes and behaviour. London: Sage.

Reinbold, F. (2015, October 24). Das bisschen Hass. Spiegel Online. Retrieved October 30, 2016, from http://www.spiegel.de/netzwelt/netzpolitik/facebook-in-dublin-das-bisschen-hassa-1059317.html.

Reinemann, C., Aalberg, T., Esser, F., Strömbäck, J., \& de Vreese, C. H. (2017). Populist political communication: Toward a model of its causes, forms, and effects. In T. Aalberg, F. Esser, C. Reinemann, J. Stromback, \& C. H. de Vreese (Eds.), Populist political communication in Europe (pp. 12-28) London and New York: Routledge.

Reinfrank, T., \& Brausam, E. (2016). Rechter Terror gegen Flüchtlinge - Die Rückkehr der Rechten Gewalt der 1990er Jahre. In O. Decker, J. Kiess, \& E. Brähler (Eds.), Die enthemmte Mitte. Autoritäre und rechtsextreme Einstellung in Deutschland (pp. 235-244). Giessen: Psychosozial.

Riechers, K. (2015, July 30). Stadt München ruft Katastrophenfall aus. Bild. Retrieved October 31, 2016, from http://www.bild.de/regional/muenchen/fluechtling/zu-vielefluechtlinge-stadt-muenchen-ruft-katastrophenfall-aus-42009138.bild.html. 
Shields, R. (2003). The Virtual. London and New York: Routledge.

Shields, R. (2006). Virtualities. Theory, Culture \& Society, 23(2-3), 284-286.

Spiegel Online. (2016, September 24). Fremdenfeindliche Gewalt drastisch gestiegen.

Retrieved October 31, 2016, from http://www.spiegel.de/politik/deutschland/fluechtlingerechte-gewalt-gegen-auslaender-nimmt-zu-a-1113669.html.

Sunstein, C. (2001). Republic.com. Princeton, NJ: Princeton University Press.

Sunstein, C. (2007). Republic.com 2.0. Princeton, NJ: Princeton University Press.

Patton, D. U., Hong, J. S., Ranney, M., Patel, S., Kelley, C., Eschmann, R., \& Washington, T. (2014). Social media as a vector for youth violence: A review of the literature. Computers in Human Behavior, 35, 548-553.

Welt. (2016, September 30). Deutschland korrigiert Flüchtlingszahl für 2015. Retrieved July 31, 2016, from https://www.welt.de/politik/deutschland/article158465433/Deutschlandkorrigiert-Fluechtlingszahl-fuer-2015.html.

Yates, C. (2015). The play of political culture, emotion and identity. Basingstoke and New York: Palgrave MacMillan. 
Zeit Online. (2016, June 1). Lernt einfach mal einen Flüchtling persönlich kennen. Retrieved

October 31, 2016, from http://www.zeit.de/gesellschaft/zeitgeschehen/2016-06/angela-

merkel-fluechtlingspolitik-verteidigung-bunte-interview.

' Other names in frequent use now are Widerstand ('resistance') + [name of the region/town/city], e.g.
'Widerstand Berlin,' or [name of the region/town/city] wehrt sich ('fights back'), e.g. 'Parchim wehrt sich' (see
also Giesler 2016).
ii If not indicated otherwise, all translations from German to English are mine.
iii Of 5,000 questionnaires sent out, 2,420 were answered and returned, which amounts to a response rate of 49.9
percent. (Decker et al. 2016b, p.26)
iv Whereas most pages claim to be independent from party politics (see Giesler 2016), party affinities of Nein
zum Heim pages can easily be identified from the main posts and the users' comments in response to them.
These affinities range from extreme-right positions compatible with the National Party of Germany (NPD), to
the more moderate right-wing AfD. A post on 'Nein zum Heim in Köpenick,' published the day before the
county elections in Berlin and Brandenburg, captures the relation between the two parties well: 'Squares vote
AfD, real men NPD,' reads the banner, signed by the Young Nationalists (JN). Arguably, this reveals the
ideological range of page administrators and users and the dramatis personae on the 'Nein zum Heim' pages.
v For example: 'I am afraid for my children!!!! Now is the time to wake up!' ('Nein zum Heim in Guben,' 6
January 2016); 'Now some of our citizens seem to wake up, common sense is setting in' ('Nein zum Heim in
Schwarzwald-Beer-Heuberg,' 30 January 2016); 'When does this damn state finally wake up and see that we are
on the brink of disaster?' ('Nein zum Heim in Oranienburg,' 25 August 2016).

${ }^{\mathrm{vi}}$ Against a view of human existence as defined by what the political anthropologist Helmut Plessner (1982) calls 'eccentric positionality,' i.e. a mode of existence that is reflexive in that a person does not only experience life, but also experiences his/her own experience (Plessner 1982, p.10), we cannot ever conceive of symbolic acts as directly triggering acts of violence. After all, the assumption of such a direct cause-and-effect chain must fall short of the reflexive mode of experiencing that defines us as human. However, with the help of psychoanalytic theories it is possible, for example, to approach an understanding of the powers that impede and inhibit this kind of reflection or that lead it to take on and accept (psycho-)logics that justify and redeem a departure from symbolic means of contention. It is that which I will do in this article.

vii However, there are studies on similar phenomena in existence that have informed the present article, most importantly: Neumayer 2016; Berntzen and Weisskircher 2016.

viii All numbers relating to the Facebook pages presented in this chapter are from autumn 2016 and might have been subject to changes over time.

ix The number of 'likes' ranged from below 10 to above 1,000; 'shares' from zero to into the hundreds; and the number of comments ranged from zero to up into the forties.

${ }^{x}$ On the Guben page, for example, the balance of comments from users with male and female names is 10 to two (i.e. 80 percent of comments come from male users, 20 percent from female users). On the Köpenick page, it is 10 to three (i.e. 70 percent to 30 percent). This seems characteristic for all pages looked into. With their defensive posture, they seem to be generally understood as male domains.

${ }^{x i}$ Indeed, submitting the analysed posts on the Köpenick to a word list check shows that the word 'info' is the second most used noun on the page after 'Berlin,' with the phrase 'Zur Info' being used 74 times (out of 330 instances of 'info').

xii In terms of frequency of usage on the Guben page, the word Einzelfall and the plural form Einzelfälle together (53 mentions in posts during the analysed time) put the word on a par with Flüchtlinge ('refugees,' 58 mentions) and Volk ('people,' 53 mentions).

xiii That is, exactly those sources discredited by the page owners as well as other right-wing publications belonging to the 'lying press,' a term originally coined during the Nazi reign in Germany (1933-1945) and made popular again by the PEGIDA movement.

xiv 'Nein zum Heim in Schwarzwald-Beer-Heuberg,' for example, shares three items from bz-berlin.de, two from ruhraktuell.com, one from niederlausitz-aktuell.de, two from wochenblick.at, nine items from krone.at, etc. ${ }^{x v}$ This conception of condensation is related to Freud's use of the term. Freud conceived of condensation as a central dream mechanism, and 'one of the central modes of the functioning of the unconscious processes: a sole idea represents several associative chains at whose point of intersection it is located' (see discussion of 'condensation' in Laplanche and Pontalis 1973). 
xvi With 42 mentions, 'evening walk' (Abendspaziergang) is the second most used noun on the page, after 'Oranienburg' (59 mentions) and before 'Brandenburg' (39 mentions). 